\title{
Reflection on Learning to Read Japanese Language Through Contextual Approach for Indonesian Students
}

\author{
Frida Philiyanti $^{1, a)}$, Yumna Rasyid ${ }^{1)}$, Emzir $^{1)}$ \\ Pendidikan Bahasa Jepang, Fakultas Bahasa dan Seni, Universitas Negeri Jakata, \\ Jakarta, Indonesia \\ E-mail: ${ }^{a)}$ fridaphiliyanti@unj.ac.id
}

\begin{abstract}
In the term of language skills, reading skills are advanced skills after listening and speaking. For learners of foreign languages, in this case is Indonesian students, the urge in mastering this skill becomes a massive obstacle. Especially in learning Japanese, the most common problem encountered is the difference in writing characters, vocabulary, and grammar compared to Indonesian. As an effort to help students overcome these problems, reading learning through a contextual approach is carried out for first semester students in Japanese Language Study Program, Faculty of Languages and Arts, Universitas Negeri Jakarta. One component in the contextual approach to learning is reflection. Through this activity, students are expected to find a connection between information or knowledge they gained with their daily experiences. Thus, they will find the meaning of learning. This study aimed to determine the impact of self-reflection and its relation to the ability to read Japanese for beginner-level Indonesian students. This research method uses descriptive analysis method. From the reflections of 20 Indonesian students who were learning Japanese for the first time show that vocabulary skills were the most supportive factor in mastering reading skills compared to grammatical abilities.
\end{abstract}

Keywords: Japanese reading, contextual approach, reflection, Indonesian students

\begin{abstract}
Abstrak
Dalam hal keterampilan berbahasa, keterampilan membaca adalah keterampilan tingkat lanjut setelah mendengarkan dan berbicara. Bagi pelajar bahasa asing, dalam hal ini adalah siswa Indonesia, keinginan menguasai keterampilan ini menjadi hambatan besar. Khususnya dalam belajar bahasa Jepang, masalah yang paling umum ditemui adalah perbedaan dalam penulisan huruf, kosakata, dan tata bahasa dibandingkan dengan bahasa Indonesia. Sebagai upaya untuk membantu siswa mengatasi masalah ini, pembelajaran membaca melalui pendekatan kontekstual dilakukan untuk siswa semester pertama di Program Studi Bahasa Jepang, Fakultas Bahasa dan Seni, Universitas Negeri
\end{abstract}


Jakarta dengan menekankan aktivitas refleksi. Salah satu komponen dalam pendekatan kontekstual dalam proses pembelajaran adalah refleksi. Melalui kegiatan ini, siswa diharapkan untuk menemukan hubungan antara informasi atau pengetahuan yang mereka peroleh dengan pengalaman sehari-hari mereka. Dengan demikian, mereka akan menemukan makna belajar. Penelitian ini bertujuan untuk mengetahui dampak refleksi diri dan hubungannya dengan kemampuan membaca bahasa Jepang untuk pelajar Indonesia tingkat pemula. Metode penelitian ini menggunakan metode analisis deskriptif. Dari refleksi 20 siswa Indonesia yang belajar bahasa Jepang untuk pertama kalinya, ditemukan bahwa keterampilan kosakata adalah faktor yang paling mendukung dalam penguasaan keterampilan membaca dibandingkan dengan kemampuan tata bahasa.

Kata kunci: membaca bahasa Jepang, pendekatan kontekstual, refleksi, mahasiswa Indonesia

\section{PENDAHULUAN}

Membaca merupakan proses interaktif antara pembaca dan teks bacaan yang menuntut pemaknaan. Dalam proses tersebut, pembaca berinteraksi secara dinamis dengan teks untuk memperoleh makna melalui dua cara, yaitu melalui wawasan kaidah kebahasaan serta wawasan skematis (Alyousef, 2006). Sebagai suatu proses, aktivitas membaca melibatkan cara-cara pemaknaan teks yang akan bervariasi sesuai dengan karakteristik teks, tujuan pembaca, dan konteks situasi (Antoni, 2010). Dalam pemahaman yang lebih luas, membaca dapat dianggap sebagai pusat proses belajar. Melalui membaca, mahasiswa memperoleh informasi dan wawasan yang lebih luas dalam mempelajari suatu topik (Halik, 2016; Purwahida, 2017; Purwahida, 2018).

Membaca dalam bahasa Jepang memiliki kendala tersendiri sesuai dengan keunikan bahasa. Dari sudut aspek linguistik, karakteristik bahasa Jepang dapat dilihat baik dari huruf, kosakata, sistem pengucapan, dan tata bahasa (Sudjianto \& Dahidi, 2004). Dalam hal huruf, bahasa Jepang terdiri atas kanji, yaitu simbol yang memiliki makna, dan dua jenis huruf seperti hiragana dan katakana.

Mahasiswa Indonesia harus berjuang untuk memahami arti dari teks Jepang, terlebih lagi karena tidak ada spasi dalam teks tertulis Jepang. Penelitian ini berfokus pada pembelajaran membaca melalui pendekatan kontekstual yang menekankan pentingnya menafsirkan daripada mengingat.

Pendekatan kontekstual merupakan pendekatan yang lahir dari pemikiran bahwa sebuah pembelajaran akan bermakna apabila terdapat hubungan antara isi dan konteksnya. Dengan kata lain konteks akan memberikan makna pada isi. Diamond dan Hopson dalam Johnson (2002) menjelaskan bahwa "begitu otak menemukan makna, struktur fisiknya akan berubah seiring dengan pembentukan hubungan saraf'. Cara kerja otak yang terus menerus mencari makna untuk disimpan dalam memori turut mempengaruhi proses belajar seorang individu. Oleh karena itu, proses pembelajaran pun harus melibatkan pencarian makna agar tersimpan dalam memori mahasiswa.

Refleksi merupakan salah satu tahapan pembelajaran yang ada pada pendekatan kontekstual tersebut. Refleksi adalah cara berpikir tentang apa yang baru saja dipelajari atau berpikir kembali tentang apa yang telah kita alami di masa lalu (Nurhadi, 2002). Dalam pembelajaran membaca, refleksi merupakan atribut esensial untuk 
membelajarkan literasi (Roskos, Vuskelich, \& Risko, 2001). Dalam penerapannya, membaca refleksi berperan untuk menghubungkan pengetahuan masa lalu dengan pengetahuan baru yang didapat setelah membaca. Dalam model pembelajaran, aktivitas membaca refleksi diperkenalkan secara eksplisit dalam model membaca SQ3R, SQ4R, dan PQ3R. Ketiga model tersebut memiliki kesamaan dalam tahap akhir proses pembelajaran yaitu "R" atau Refleksi. Penelitian terdahulu, di antaranya penelitian Agustina dan Hariyadi (2018), membuktikan bahwa hasil belajar membaca pada mahasiswa program studi pendidikan bahasa Indonesia dengan metode SQ3R dan PQ3R menunjukkan peningkatan yang tergolong baik.

Metode tersebut adalah salah satu cara bagi mahasiswa untuk mengevaluasi diri. Aktivitas tersebut bertujuan untuk mengendapkan pengetahuan baru yang diperoleh dan mempersiapkan strategi pembelajaran yang lebih baik pada pelajaran selanjutnya. Dalam proses refleksi, dosen berfungsi sebagai fasilitator yang membantu siswa menemukan makna dari teks atau pelajaran (Costa \& Kallick, 2008). Dalam kegiatan membaca, dosen meminta siswa untuk memikirkan kembali apa yang telah mereka peroleh setelah membaca, ini bukan hal yang mudah terutama bagi siswa yang belum pernah melakukan refleksi dalam proses belajar sebelumnya. Biasanya siswa akan dengan mudah menjawab, "Membaca itu sulit" atau "Membaca itu mudah", "Saya mengerti", dan sebagainya. Namun, situasi yang terjadi malah sebaliknya. Ketika siswa dihadapkan dengan ujian dengan bahan yang sama dengan yang baru saja dibaca, mereka umumnya merasa sulit untuk menjawab. Dengan demikian, dapat disimpulkan bahwa jawaban mahasiswa tidak benar-benar merepresentasikan pemahaman, kemampuan, maupun minat mahasiswa.

Selain itu, derasnya arus informasi setelah revolusi industry di era sekarang telah menyebabkan degradasi sisi humanis, terutama pada generasi anak muda yang secara mental tidak benar-benar matang. Dampak tidak langsung yang dirasakan di bidang pendidikan adalah ketergantungan siswa pada gawai, yang secara kejiwaan mempengaruhi mahasiwa untuk mendapatkan nilai tinggi di kelas dengan cara instan, kurangnya konsentrasi sebelum atau selama pelajaran, dan sebagainya. Di sisi lain, tuntutan untuk mencapai target pembelajaran pun terkadang membuat pengajar kurang memperhatikan aspek pembelajaran selain aspek kognitif.

Pada situasi demikian, dosen berperan membimbing siswa untuk merenungkan hal-hal yang berkaitan dengan proses dan hasil belajar mereka. Refleksi dapat dilakukan dengan diskusi, evaluasi diri, atau portofolio (Costa \& Kallick, 2008; Alderete, 2008). Pendekatan kontekstual dalam pembelajaran adalah pendekatan yang secara aktif melibatkan dosen dan siswa melalui pembelajaran kooperatif dan refleksi, sehingga setiap siswa mengetahui peran dan tanggung jawab mereka demi keberhasilan dalam mencapai hasil pembelajaran (Matsumoto, 2007).

Refleksi adalah salah satu kegiatan dalam proses pembelajaran kontekstual di mana mahasiswa dituntut untuk merefleksikan pengetahuan mereka, memahami kelemahan dan kekuatan mereka sehingga mereka sendiri menentukan strategi pembelajaran yang cocok untuk mereka. Refleksi adalah bagian dari pembelajaran mandiri, diharapkan melalui kegiatan ini peserta didik dapat lebih memahami pengetahuan baru yang mereka peroleh. Kegiatan ini sangat diperlukan dalam proses membaca, di mana menurut Alexander dan Heathington (1988), "membaca adalah proses interaktif. Membaca melibatkan interaksi dari latar belakang informasi dan minat pembaca dengan informasi yang disajikan dalam teks dan jenis tugas membaca yang terlibat." 
Berdasarkan latar belakang tersebut, penelitian ini bertujuan untuk mengetahui pengaruh refleksi dalam kegiatan membaca dalam meningkatkan keterampilan membaca literal mahasiswa, khususnya tentang bagaimana refleksi dapat memfasilitasi mahasiwa tingkat pemula dalam mengidentifikasi huruf, kata, hingga makna kalimat sederhana dalam membaca teks bahasa Jepang.

\section{METODE PENELITIAN}

Penelitian ini merupakan bagian dari penelitian pengembangan (R\&D) yang menggunakan metode deskriptif dengan fokus penelitian pada proses kegiatan pembelajaran membaca bahasa Jepang (Dokkai) melalui pendekatan kontekstual bagi mahasiswa Indonesia. Objek dalam penelitian ini adalah 20 orang mahasiswa Program Studi Pendidikan Bahasa Jepang yang belum pernah menerima pelajaran bahasa Jepang baik formal maupun informal sebelumnya. Penelitian ini bertujuan untuk meninjau dampak dari kegiatan refleksi pada proses dan hasil belajar membaca dalam bahasa Jepang (Dokkai).

\section{HASIL DAN PEMBAHASAN}

Refleksi dalam penelitian ini terdiri dari refleksi di awal, selama, dan akhir dari proses belajar membaca. Sebagaimana yang telah dikemukakan oleh Costa dan Kallick (2008) serta Alderete (2008), metode yang digunakan untuk melakukan refleksi adalah kuesioner, evaluasi diri, dan portofolio. Refleksi pada awal proses pembelajaran menggunakan kuesioner yang bertujuan untuk mengetahui kondisi awal dan minat siswa terkait membaca bahasa Jepang. Dari hasil kuesioner, diketahui beberapa hal seperti diilustrasikan dalam grafik berikut.

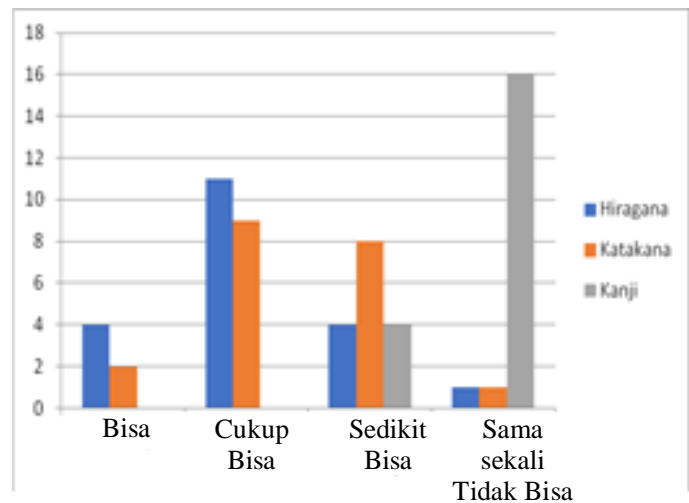

GAMBAR 1. Diagram Kondisi Awal Penguasaan Huruf Bahasa Jepang

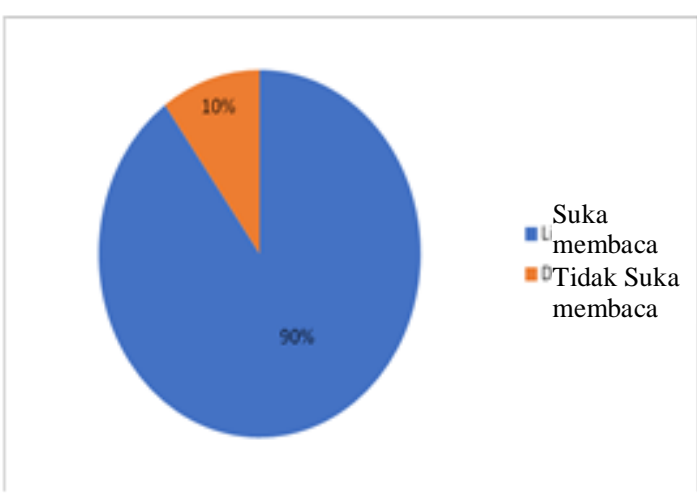

GAMBAR 2. Diagram Minat Membaca Mahasiswa

Seperti yang ditunjukkan pada Gambar 1, tidak ada jenis huruf yang dikuasai oleh $100 \%$ mahasiswa. Meskipun demikian, lebih dari 50\% mahasiswa akrab dengan 
hiragana, dan hampir semua mahasiswa tidak menguasai kanji. Dari Gambar 2, dosen dapat mengetahui bahwa hanya sebagian kecil mahasiswa yang tidak suka membaca bahasa Jepang. Hasil tersebut tentu memudahkan dosen untuk merancang kegiatan belajar.

Sebagai bagian dari penelitian $R \& D$, penelitian ini bertujuan untuk mengembangkan model pembelajaran yang efektif untuk meningkatkan keterampilan membaca dalam bahasa Jepang. Refleksi dalam bentuk portofolio didistribusikan kepada mahasiswa yang harus diisi pada kuartal pertama proses pembelajaran. Dalam portofolio, mahasiswa menuliskan harapan dan strategi pembelajaran yang akan mereka lakukan selama proses belajar. Portofolio kemudian diisi ulang pada akhir kuartal pertama untuk mengetahui apakah target mereka tercapai atau tidak. Hasil dari pengumpulan portofolio tersebut dapat dilihat pada grafik berikut.

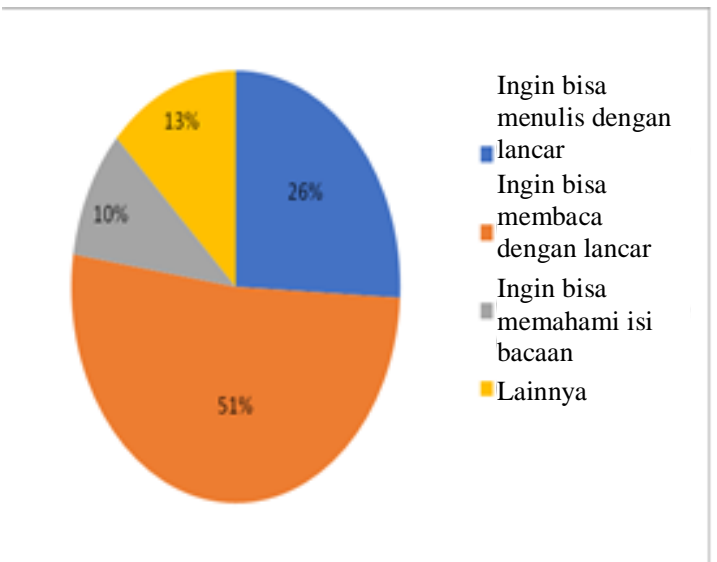

GAMBAR 3. Diagram Harapan Awal Pembelajar Pemula pada Pembelajaran Membaca

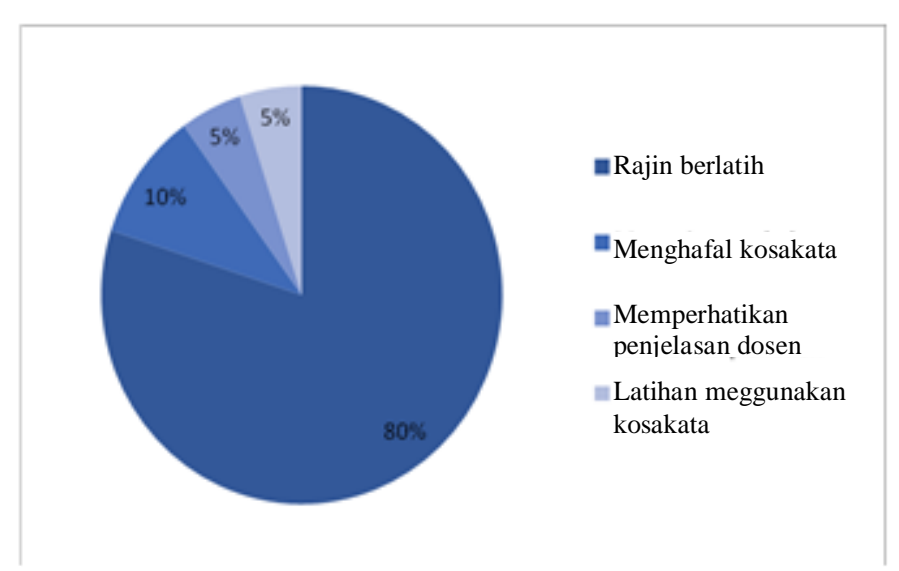

GAMBAR 4. Diagram Rencana Strategi Belajar

Seperti yang terlihat pada Gambar 3, 51\% mahasiswa berharap mereka akan dapat membaca bahasa Jepang dengan lancar. Hal ini kemudian direfleksikan kembali di akhir kuartal pertama dan diketahui bahwa ada beberapa mahasiswa yang masih tersendat dalam membaca teks berbahasa Jepang. Akan tetapi, Gambar 4 menunjukkan $80 \%$ mahasiswa menetapkan bahwa rajin berlatih membaca adalah cara mereka untuk mencapai target pembelajaran. Ketika dievaluasi di akhir kuartal pertama, diketahui bahwa mahasiswa telah dapat menulis dengan menggunakan hiragana dan katakana dengan baik.

Berdasarkan kondisi tersebut, mahasiswa diminta untuk mendiskusikan kelemahan dan kekuatan dari strategi pembelajaran mereka. Berlatih dan menghafal tidak cukup untuk meningkatkan keterampilan membaca literal. Hal tersebut disebabkan oleh karakteristik teks Jepang merupakan teks tanpa spasi. Oleh karena itu, mahasiswa perlu memahami apa yang dia baca, bukan hanya mengingat huruf per huruf. Hasil penelitian ini pun menunjukkan bahwa refleksi yang dilakukan oleh mahasiswa sudah berada pada tingkat critical reflection atau refleksi kritis. Hal tersebut ditandai dengan adanya kesadaran bahwa pemahaman dan tindakan mahasiswa dalam mempelajari keterampilan membaca dalam bahasa Jepang tidak hanya dipengaruhi oleh pemahaman mereka tentang kaidah aksara dan gramatika bahasa Jepang, tetapi oleh pemahaman 
tentang makna kata dan konteks penggunaannya (Nurfaidah, Lengkanawati, \& Sukyadi, 2017).

Selanjutnya, refleksi selama proses pembelajaran dilakukan melalui evaluasi diri dalam bentuk lembar evaluasi diri. Pada proses tersebut, mahasiswa mulai mengenali kekuatan dan kelemahan masing-masing. Mahasiswa diminta untuk menuliskan informasi apa yang mereka peroleh dari bacaan, kemudian mereka juga diminta untuk mendiskusikan pencapaian mereka. Pada tahap tersebut, mahasiswa mendapatkan informasi tambahan tentang strategi belajar dari teman-teman lain. Selain itu, mahasiswa juga secara tidak langsung dilatih untuk mengekspresikan prestasi mereka sehingga dapat menghasilkan kepercayaan diri dan motivasi dalam belajar. Hasil evaluasi diri adalah hasil evaluasi diri mahasiswa atas prestasi mereka setelah belajar disajikan dalam grafik berikut.

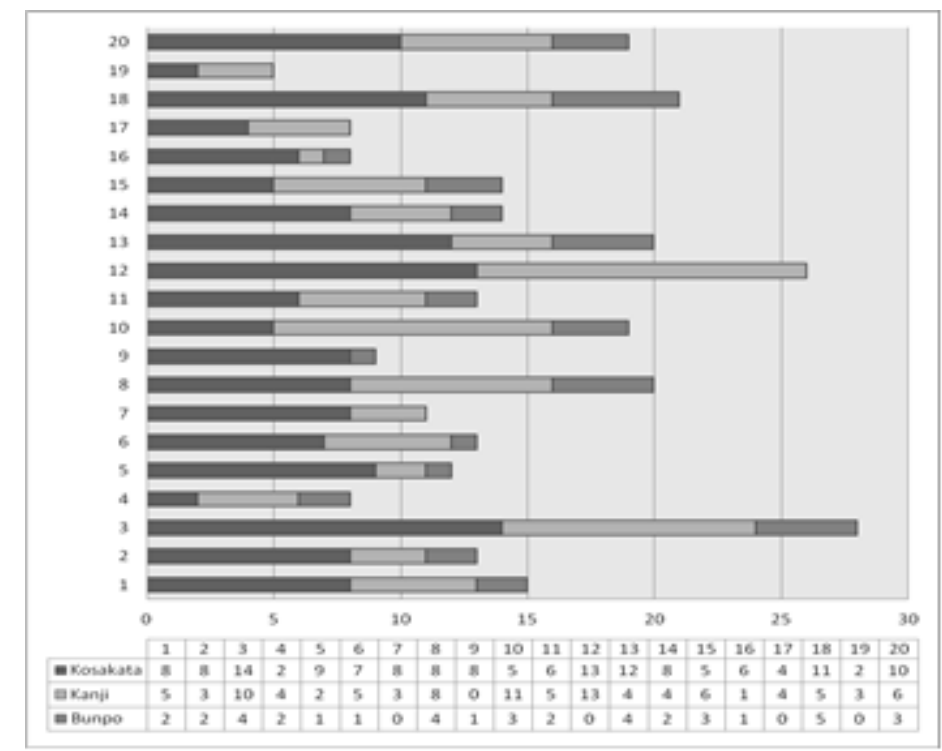

GAMBAR 5. Grafik Pencapaian dalam Pembelajaran Membaca melalui Evaluasi Diri setelah Proses Pembelajaran

Dari Gambar 5, terlihat bahwa kosakata baru adalah komponen yang paling dikuasai setelah membaca. Selanjutnya, berdasarkan data tersebut, dosen dapat menetapkan kegiatan pembelajaran selanjutnya. Hal yang dilakukan pada saat itu adalah memberikan stimulus kepada mahasiswa dengan meminta mereka untuk membuat kalimat menggunakan kosakata baru atau hanya meminta mereka untuk berbagi alasan bahwa mereka telah menguasai kosakata baru. Dari kegiatan tersebut, mahasiswa dituntut untuk menghubungkan informasi baru dengan kegunaannya dalam kehidupan sehari-hari sehingga pembelajaran menjadi lebih bermakna.

Pada akhir kuartal kedua, mahasiswa diminta untuk merenungkan kembali pencapaian target dalam pembelajaran membaca. Sebagai hasilnya, semua mahasiswa mengatakan bahwa jika teks tidak ditulis dalam kanji, mereka bisa membaca dengan lancar. Hal tersebut disebabkan oleh kemudahan mahasiswa dalam menjeda kata-kata dalam kalimat ketika mereka memahami makna katanya. 


\section{KESIMPULAN}

Karakteristik pembelajaran membaca bahasa Jepang melalui pendekatan kontekstual adalah peningkatan keterampilan membaca literal berdasarkan proses pemahaman makna kata, bukan pembiasaan. Refleksi adalah langkah penting dalam proses pembelajaran ini, karena, melalui refleksi, siswa secara sadar mengaitkan informasi baru yang mereka peroleh dengan pengalaman masa lalu atau kegunaannya di masa depan. Sebagai sebuah proses yang berjalan secara individual, refleksi tidak hanya meliputi kemampuan kognitif seperti yang sering dilakukan oleh pengajar konvensional, tetapi juga melibatkan kemampuan afektif yang diasumsikan sebagai proses yang sesuai untuk bertahan di era revolusi industri 4.0. Melalui refleksi, baik sebelum, selama, maupun setelah pembelajaran, mahasiswa memperoleh penguatan prestasi dan kesempatan memperbarui metode atau strategi pembelajaran untuk mencapai prestasi yang lebih baik. Dari penelitian ini ditemukan bahwa setelah dilakukan beberapa diskusi dan evaluasi diri, penguasaan kosakata adalah faktor yang paling mendukung bagi mahasiswa dibandingkan dengan kemampuan tata bahasa dalam menguasai keterampilan membaca.

\section{UCAPAN TERIMA KASIH}

Ucapan terima kasih ditujukan kepada seluruh pihak yang telah membantu peneliti dalam menyelesaikan penelitian ini.

\section{REFERENSI}

Agustina, R., \& Hariyadi. (2018). Penerapan metode SQ3R dan metode PQ3R terhadap keterampilan membaca pada mahasiswa. Aksis: Jurnal Pendidikan Bahasa dan Sastra Indonesia 2(1). 69-80. doi: https://doi.org/10.21009/AKSIS.020105

Alderete, D.P. (2008). Reflection in language teaching and learning in higher education: Is the European language portfolio the answer? In L. Pérez Ruiz, I. Pizarro Sánchez, \& E. González-Cascos Jiménez (Eds.), Estudios de Metolodogía de la Lengua Inglesa (IV). Valladolid, Spain: Ediciones Universidad de Valladolid. Retrieved from https://aran.library.nuigalway.ie/handle/10379/6654

Alexander, J.E., \& Heatington, B.S. (1988). Assessing and Correcting Classroom Reading Problems. Glenview: Scott Moresman.

Alyousef, H.S. (2006). Teaching reading comprehension to ESL/EFL learners. Language Learning Journal, 5(1), 143-154.

Antoni, N. (2010). Exploring efl teachers' strategies in teaching reading comprehension. Jurnal Penelitian Pendidikan, 11(2), 39-51.

Costa, A.L., \& Kallick, B. (2008). Learning through reflection. Learning and leading with habits of Mind. Virginia: Association for Supervision and Curriculum Development. 
Halik, N. (2016). Contextual teaching and learning method in teaching reading at third year students of MTsN Balang-Balang Gowa regency. ETERNAL (English, Teaching, Learning and Research Journal), 2(2), 147-166. doi: https://doi.org/10.24252/Eternal.V22.2016.A1

Johnson, E. B. (2002). Contextual Teaching and Learning: What It Is and Why It's Here to Stay. California: Corwin Press.

Matsumoto, K. (2007). Amerika no kyaria kyouiku ni okeru bunmyakutekina kyoujugakushuu (contextual teaching and learning') no tokushitsu. Japanese Soc. Curric. Stud., 49, 15-28. doi: https://doi.org/10.18981/jscs.16.0_15

Nurfaidah, S., Lengkanawati, N.S., \& Sukyadi, D. (2017). Levels on EFL pre-service teachers' teaching journal. Indonesian Journal of Applied Linguistic, 7(1), 8092. doi: 10.17509/ijal.v7i1.6861

Nurhadi. (2002). Pendekatan Kontekstual: Contextual Teaching and Learning (CTL). Malang: Universitas Negeri Malang

Purwahida, R. (2017). Interaksi sosial pada kumpulan cerpen Potongan Cerita di Kartu Pos karangan Agus Noor dan implikasinya terhadap pembelajaran sastra di SMA. Aksis: Jurnal Pendidikan Bahasa dan Sastra Indonesia 1(1). 118-134. doi: doi.org/10.21009/AKSIS.010107

Purwahida, R. (2018). Problematika Pengembangan Modul Pembelajaran Baca Tulis Anak Usia Sekolah Dasar. Aksis: Jurnal Pendidikan Bahasa dan Sastra Indonesia 2(1). 118-134. doi: doi.org/10.21009/AKSIS.020108

Roskos, K., Vukelich, C., \& Risko, V. (2001). Reflection and learning to teach reading: A critical review of literacy and general teacher education studies. Journal of Literacy Research, 33(4), 595—635. doi: 10.1080/10862960109548127

Sudjianto, \& Dahidi, A. (2004). Pengantar Linguistik Bahasa Jepang. Jakarta: Kesaint Blanc. 